\title{
Molecular Characterization of the Yeast Isolates Originating from Turkish Autochthonal Product, Brined Grapeleaves
}

\author{
Mehmet Caglar Firat \\ Department of Hotel, Restaurant and Service, \\ Tourism and Hospitality Vocational School, \\ Erzincan Binali Yıldırım University \\ Erzincan, Turkey
}

\author{
Bulent Cetin \\ Department of Food Engineering, \\ Faculty of Agriculture, Atatürk University \\ Erzurum, Turkey
}

\begin{abstract}
Yeast isolates collected from brined grapevine were identified using molecular methods. A total number of 54 isolates were collected. The isolates were grouped into 12 spieces depending upon their phenotypic disparities. RAPD and sequence analyses were used as molecular step. Due to high concentrations of salt and low $\mathrm{pH}$ in this product, brined grape leaves did not showed expected fermentation model, salt resistance yeasts were identified. As a result, Pichia subpelliculosa, Debaryomyces hansenii, Zygosaccharomyces bisporus, Pichia membranifaciens, Hanseniaspora uvarum were found predominant species.
\end{abstract}

Keywords-M13, grapevine, yeast, 26s rRNA,

\section{INTRODUCTION}

Turkish cuisine has been focus of attention for many people. One of the most famous item of the cuisine is 'brined grapevine' used for preparing 'dolma'. This product is also consumed at Balcan, Middle East and Caucasian countries. Despite consumed by a high number of population, research about the microflora of traditional brined grape leaves are limited. Viticulture is mainly carried out for grape, winemaking and dried grapes. Grapevine ( $V$. vinifera) is edible parts of vine leaves which is commonly conserved by brining. Even though consuming of grapevine is not common worldwide, Codex Alimentarius classified vine lives in leafy vegetables [7]. This product is mentioned as fermented vegetable at various articles [3][5][11]. To evaluate this data we identified the microflora of brined grape leaves at our previous research. Hovewer, microflora of brined grape leaves consists of yeast species [8]. This data showed that the product does not have expected fermentation model. Fermented foods may contain yeasts however, lactic acid bacteria are must also be isolated to be classified as fermented. Yeasts are eukaryotic, single celled, aerobic or facultative anaerobic microorganisms which are commonly isolated from sugar-rich environments like fruits, juices, and also other foods. Despite some yeast species such as Saccharomyces and Brettanomyces are directly related with fermentation, yeasts are commonly known as spoiling microflora because, they can metabolize organic acids and other carbon sources which may be main ingredient of the food. In this research, characterization of the yeasts isolated from brined grapevine was performed.

\section{MATERIALS AND METHODS}

\subsection{ISOLATION OF YEASTS}

Potato dextrose Agar (PDA) (Merck) and Yeast Extract Glucose Chloramphenicol Agar (YGC) (Merck) were used for selective isolation of yeasts. By paying attention both microscopic and phenotypic disparities, different colonies was collected and stored in LB Broth (Merck) and $80 \%$ Glicerol at $-80^{\circ} \mathrm{C}$.

\subsection{DNA EXTRACTION FOR PCR}

Isolation and purification of DNA were performed according to Looke et al [15]. Young cell volume 100-200 $\left(\mathrm{OD}_{600}=0,4\right)$ was measured out and suspended into $1 \mathrm{ml}$ distilled water. This suspension was vortexed 3 minutes at 20000g and supernatant was poured out. $100 \mu \mathrm{l} 200 \mathrm{mM} \mathrm{LiOAc+ \% 1} \mathrm{SDS}$ solution was added on pellet. After vortexing, the mix was incubated 5 minutes at $70^{\circ} \mathrm{C} .300 \mu 196 \%$ ethanol was added to suspension. After vortexing, samples were centrifugated 3 minutes $15000 \mathrm{~g}$ at room temprature. Mixture was washed in $300 \mu \mathrm{l} 70 \%$ ice cold ethanol and it was followed by centrifugating mixture 15 seconds at $15000 \mathrm{~g}$. Finally ethanol removed and mixture was conserved at $-20^{\circ} \mathrm{C}$ in $50 \mu \mathrm{l} \mathrm{TE}$ solution. $1 \mu$ l supernatant was used for PCR.

\subsection{RAPD ANALYSIS}

RAPD fingerprints was obtained from the yeasts genomic DNA's, using bacteriophage M13 primer. Thus, both costs reduced and also strain diversity determined. Amplification reaction was performed in a total $50 \mu \mathrm{l}$ mix containing $25 \mu \mathrm{l}$ PCR master mix (Qiagen), $18 \mu \mathrm{l}$ water, $4 \mu$ template DNA, 3 $\mu 1$ M13 primer (5'-GAGGAGGGTGGCGGTTCT-3'). Amplification procedure was held as mentioned above: $94^{\circ} \mathrm{C}$ 4 ' first denaturation, $94^{\circ} \mathrm{C}$ denaturation $30 \mathrm{~s}$, annealing at $36^{\circ} \mathrm{C} 45 \mathrm{~s}, 45 \mathrm{~s}$ elongation at $72^{\circ} \mathrm{C}$. After PCR cycle RAPDPCR was separated by electrophoresis on $1.2 \%(\mathrm{w} / \mathrm{v})$ agarose gel in SB buffer with DNA size marker (Qiagen) using horizontal electrophoresis system (Biolab). Gels were stained with ethidium bromide, visualized under UV light and digitalized using (Uvitech) [24].

\subsection{ITS-PCR AND GEL ELECTROPHORESIS}

The fingerprints obtained from the isolates were grouped into their disparities. One sample was chosen for all groups and 
26S rRNA D1/D2 section (600bp) of all chosen represantives were amplified. PCR mix contained $15 \mu \mathrm{l}$ master mix (Qiagen),

0,5 $\mu \mathrm{l} \mathrm{NL-1} 5$ '-GCATATCAATAAGCGGAGGAAAAG-3'), 0,5L NL-4 (5'-GGTCCGTGTTTCAAGACGG-3'), $3 \mu \mathrm{l}$ template DNA, $11 \mu \mathrm{l}$ water. PCR program was performed as followed: $95^{\circ} \mathrm{C} 15$ minutes first denaturation, 35 cycles of $96^{\circ} \mathrm{C} 30$ seconds denaturation, $50^{\circ} \mathrm{C} 15 \mathrm{~s}$ annealing, $68^{\circ} \mathrm{C} 2$ minutes elongation and finally $72^{\circ} \mathrm{C} 10$ minutes elongation. PCR products were separated on $\% 1$ agarose gel [23,12]. After separation amplicons were sequenced followed by purification according to Lõoke et. al 2012 [14]. Sequencing process was executed by service procurement. Outcomes evaluated by BLAST (http://blast.ncbi.nlm.nih.gov/Blast.cgi) program [10].

\section{RESULTS AND DISCUSSION}

Yeasts can be found in soil and grapes as natural flora. It is known that grape microflora mainly consists of yeast species and various lactic acid bacteria such as Lactobacillus, Pediococcus, Leuconostoc and Oenococcus. Although this microflora is thought to be able to transferred to the vine leaves, it cannot develop at low salt content in the leaves and high salt rates such as $9-12 \%$ when pickled.

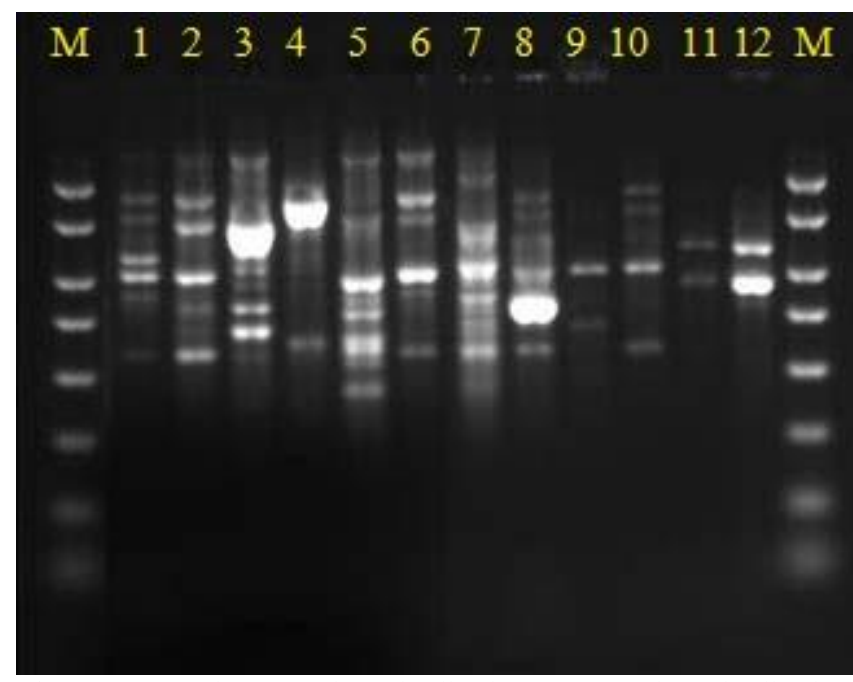

Figure 1. M: Marker, 1: Pichia subpelliculosa (8), 2: Pichia subpelliculosa (13), 3: Debaryomyces hansenii (15), 4: Zygosaccharomyces bisporus 17), 5 . Pichia membranifaciens (19), 6: Pichia subpelliculosa (22), 7: Pichia membranifaciens (33), 8: Pichia subpelliculosa (34), 9: Debaryomyces hansenii (57), 10: Pichia subpelliculosa (71), 11: Hanseniaspora uvarum (77), 12: Hanseniaspora uvarum (78)

By paying attention both microscopic and phenotypic disparities, different colonies was collected. A total number of 54 isolates were obtained from the samples. When fingerprints of the samples examined, these 54 isolates were grouped into 12 candidate species. RAPD profiles are shown at Figure 1. Pichia was found as the predominant species. Prior to sequence analyze 26S rRNA D1/D2 sections of these 12 samples were amplified and separated on gel electrophoresis in order to ensure sequencing expected $600 \mathrm{~kb}$ DNA fragments.

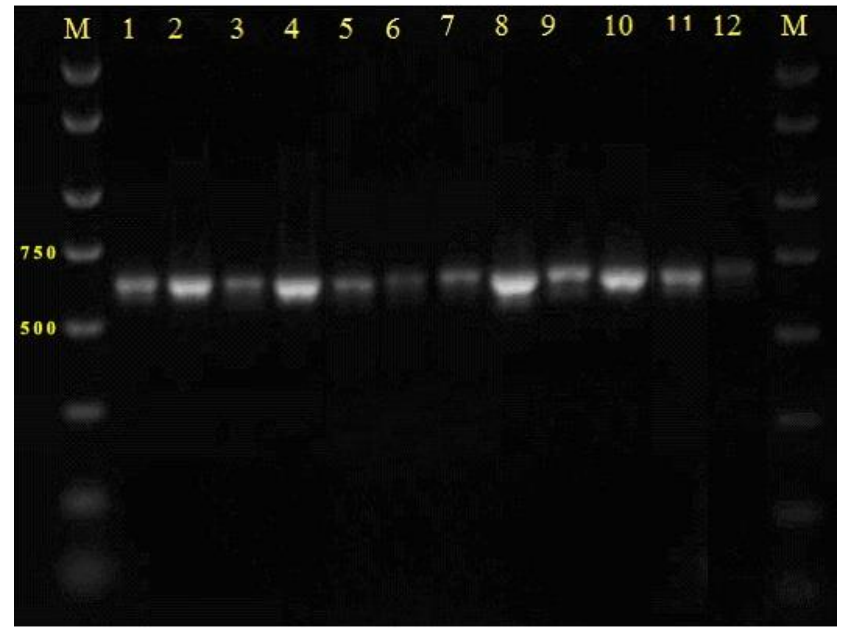

A. Figure 2. 26S rRNA D1/D2 sections of the samples

Food spoilage yeasts are commonly resistant to osmotic stress caused by salt, sugar and acidity. For instance the yeast Debaryomyces hansenii which was isolated from saline environments such as sea water, concentrated brines, salty food, is one of the most halotolerant species. It can grow in media containing as high as $4 \mathrm{M} \mathrm{NaCl}$, which is almost $25 \%$ salt concentration [21]. Yeast population in food varies depending on the production method. The yeast flora of pickles with a high salt concentration of $15 \%$ and above and other vegetable brines with a salt concentration of $5 \%$ and below differs. In traditional production method salt concentrations vary a wide range due to non-standart production. The salt concentration of brined grapevine samples in this study reached up to $\% 24$ salt concentrations.

\begin{tabular}{|c|c|}
\hline Stage & Prevalent microorganisms \\
\hline 1-Initation & Various Gram (+) and Gram (-) bacteria \\
\hline 2-Primary fermantation & Lactic acid bacteria and yeasts \\
\hline 3-Secondary & Yeasts \\
fermantation & Aerobic: Surface growth of oxidative yeasts, \\
molds and bacteria, \\
Anerobic: None
\end{tabular}

TABLE 1. Sequence of microbial types during natural fermentation of brined vegetables [2] 
As can be seen from the Table 1 , fermentation in vegetables is carried out by various lactic acid bacteria (LAB) and yeast species. LAB's involved in food fermentation are; Carnobacterium, Enterococcus, Lactobacillus, Lactococcus, Leuconostoc, Oenococcus, Pediococcus, Streptococcus, Tetragenococcus, Weisella (Wessels 2004). Important yeasts are Saccharomyces spp., Kluyveromyces spp. fermentative yeasts such as and Hansenula spp., Pichia spp., Candida spp. and oxidative yeasts such as Debaryomyces hansenii. In addition to these microorganisms, mesophile aerobic bacteria, coliform bacteria and different yeasts can also contribute vegetable fermentation [12] Two main yeast groups play a role in fermentation. The first of these are yeasts that make alcoholic fermentation in brine and form the desired aromatic by-products as long as they are fermentable sugars. When the sugars are consumed, the yeast that oxidizes the acids produced by the bacteria and develops on the surface during post fermentation is the second group.

\begin{tabular}{|c|c|c|c|c|}
\hline & $\begin{array}{c}\text { Molecular } \\
\text { identification } \\
\text { result }\end{array}$ & $\begin{array}{c}\text { Rate of } \\
\text { genetic } \\
\text { similarit } \\
\mathbf{y}\end{array}$ & $\begin{array}{c}\text { Reference } \\
\text { strain no }\end{array}$ & $\begin{array}{c}\text { Number of } \\
\text { represente } \\
\text { d isolates }\end{array}$ \\
\hline $\mathbf{1}$ & $\begin{array}{c}\text { Pichia } \\
\text { subpelliculosa }\end{array}$ & $\% 99$ & EF550340.1 & 4 \\
\hline $\mathbf{2}$ & $\begin{array}{c}\text { Pichia } \\
\text { subpelliculosa }\end{array}$ & $\% 99$ & EF550340.1 & 7 \\
\hline $\mathbf{3}$ & $\begin{array}{c}\text { Debaryomyces } \\
\text { hansenii }\end{array}$ & $\% 99$ & HM988696.1 & 2 \\
\hline $\mathbf{4}$ & $\begin{array}{c}\text { Zygosacharomyces } \\
\text { bisporus }\end{array}$ & $\% 95$ & $\mathrm{AB} 375304.1$ & 2 \\
\hline $\mathbf{5}$ & $\begin{array}{c}\text { Pichia } \\
\text { membranifaciens }\end{array}$ & $\% 99$ & EU019218.1 & 3 \\
\hline $\mathbf{6}$ & $\begin{array}{c}\text { Pichia } \\
\text { subpelliculosa }\end{array}$ & $\% 98$ & JQ419775.1 & 19 \\
\hline $\mathbf{7}$ & $\begin{array}{c}\text { Pichia } \\
\text { membranifaciens }\end{array}$ & $\% 99$ & EU019218.1 & 3 \\
\hline $\mathbf{8}$ & $\begin{array}{c}\text { Pichia } \\
\text { subpelliculosa }\end{array}$ & $\% 99$ & JQ419771.1 & 3 \\
\hline $\mathbf{9}$ & $\begin{array}{c}\text { Debaryomyces } \\
\text { hansenii }\end{array}$ & $\% 95$ & EU285526.1 & 2 \\
\hline $\mathbf{1 0}$ & $\begin{array}{c}\text { Pichia } \\
\text { subpelliculosa }\end{array}$ & $\% 99$ & JQ419771.1 & 2 \\
\hline $\mathbf{1 1}$ & $\begin{array}{c}\text { Hanseniaspora } \\
\text { uvarum }\end{array}$ & $\% 99$ & JQ678687.1 & 2 \\
\hline $\mathbf{1 2}$ & $\begin{array}{c}\text { Hanseniaspora } \\
\text { uvarum }\end{array}$ & $\% 99$ & EU004081.1 & 5 \\
\hline
\end{tabular}

TABLE 2. Molecular identification results of the isolates

Spoilage in fermented vegetables is often attributed to yeasts [23] Degradation can be in the form of softening in the plant structure after enzymatic destruction of pectins or gas fermentation and bloating. Although many yeasts (eg $S$. cerevisiae, Lachancea kluyveri, and $P$. anomala) have enzymes such as pectinesterase and polygalacturonase, which have a destructive effect on plant tissues, most do not have all pectinolytic enzymes. However, when oxidative yeasts increase in numbers on the surface, they facilitate the degradation by decomposition of lactic acid and make the product more available for other microorganisms [6].
The five species isolated from product, selected as representative of the the samples with microsatelite markers are, respectively; Pichia subpelliculosa, Debaryomyces hansenii, Zygosaccharomyces bisporus, Pichia membranifaciens, Hanseniaspora uvarum. Species mentioned above could withstand high salt concentration. In addition to it, the results relate with the species isolated from fermented vegetables (Harris 1998). As a result of the experiment, it was determined that the dominant genus in the product was Pichia (75\%) and the dominant species was Pichia subpelliculosa $(64.81 \%)$ (Table2).

Katsaboxakis [14] mentioned the presence of yeast in vine leaves produced by different methods. However, there is no information about yeast species. They attributed absence of lactic acid bacteria to the low $\mathrm{pH}$ value of the leaves. Although there is no precise data on the microflora of the product, it is observed that the genetic diagnosis results overlap with the yeast species that can be found in similar products when compared with other fermented foods of fruit and vegetable origin [9], [4]). Pichia is the second largest yeast genus known for over 100 species. Pichia subpelliculosa, an amylolytic yeast, was the most dominant type of the research also known by the name Hansenula subpelliculosa [22]) and its fermentation characteristic is very similar to Saccharomyces cerevisiae [17]. It can be isolated with Debaryomyces hansenii in Cachaça production, one of the local beverages of Brazil. It is thought that P.subpelliculosa, which develops on the surface of soy products and breaks down lactic acid, may also have an oxidative effect on pickled leaves. Because it is one of the main species isolated in cucumber pickles with a high salt concentration [4].

Debaryomyces hansenii is a type of spoiling yeast that can often be seen in foods such as cheese, meat, wine, beer, fruit, and also in foods with high salt concentrations such as pickles [4] D. hansenii is common in nature because of salt tolerance, proteolytic and lipolytic enzyme capacity, metabolism of milk, fat and proteins, ability to grow low temperature and water activity [27]. Because D. hansenii is commonly found in salty products because of its ability to develop in $24 \%$ $\mathrm{NaCl}$ and low water activity such as 0.65 [19]. D. hansenii was isolated in $7.4 \%$ of leaf samples with salt concentrations up to $25 \%$.

Hanseniaspora uvarum can be isolated from apple, grape, lemon cherry and plums which is one of main deterioration factors in wines. H. uvarum can also be isolated from pickled, cocoa, olives and salads. It can develop at a maximum of 0.94 aw (salt). This yeast type can be isolated from $1.34 \%$ of all foods [4]

Pichia membranifaciens is also known as Candida valida in telemorph, which constitutes $11.1 \%$ of the samples in the experiment, can develop in low $\mathrm{pH}$ foods because of can $1 \%$ acetic acid resistance. Various studies on biocontrol about this yeast exists, which can be isolated from $4,32 \%$ of all foods. 
Zygosaccharomyces has an osmophilic character and is a yeast type that has been reported to be isolated especially from foods with a high sugar concentration. On the other hand, isolation from foods with high salt concentrations is also been reported. [18]. investigated high salt tolerant yeast flora in a pickle-like local product made from umami fruit,. In the study, 4 different RAPD fingerprints of the isolates were observed and Zygosaccharomyces bisporus and Pichia subpeliculosa species identified after the sequence of the $26 \mathrm{~S}$ rRNA D1 / D2 region.

\section{CONCLUSION}

Molecular techniques have become ordinary and common in microbiology and identification processes. RAPD-PCR reduces the analysis costs because species which showed same fingerprint does not need to be sequenced. While foodborne yeasts are not considered as pathogens, unlike fermented milks like kefir, common spoilaging features of them are reducing the nutritional value of foods and changing its characteristics. Hence, identification of yeasts in foods became requirement in order to struggle with them. Identification of the yeasts will help to perceive the spoilage mechanism and extend the shelf life.

\section{REFERENCES}

[1] Başoğlu, F., İ. Şahin, M. Korukluoğlu, V. Uylaşer, A. Akpınar, 1996 Salamura Yaprak Üretiminde Fermentasyon Sekli ve Katk Maddelerinin Kalite ve Dayanıklılığa Etkisinin Araştırılması ve Uygun Tekniğin Geliştirilmesi. Turk. J. Agric. For., 20, 535-545.

[2] Daeschel, M. A., Andersson, R. E., \& Fleming, H. P. (1987). Microbial ecology of fermenting plant materials. FEMS Microbiology Reviews, 3(3), 357-367.

[3] Dalgıç, T., \& Akbulut, N. (1988). Salamura yapraklar üzerinde bir araştırma.

[4] Deák, T. and Beuchat, L. R., 1988. Evaluation of simplified and commercial systems for identification of foodborne yeasts. Int. J. Food Microbiol. 7:135-145.

[5] Demirci, M., 2002. Beslenme Rebel Yayıncilık, İstanbu

[6] Etchells, J. L., Fleming, H. P., and Bell, T. A. 1975. Factors influencing the growth of lactic acid bacteria during the fermentation of brined cucumbers. In: Lactic Acid Bacteria in Beverages and Food (eds. Carr, J. G., Cutting, C. V., and Whiting, G. C.). Academic Press, London. pp. 281-305.

[7] FAO, 2017. Principles And Guidance On The Selection Of Representative Commodities For The Extrapolation Of Maximum Residue Limits For Pesticides To Commodity Groups. https://bit.ly/2W6wxsg (Date of access 10.12.2019)

[8] Firat, M. Ç., \& Çetin, B. (2014). Geleneksel ve Endüstriyel Yöntemlerle Üretilmis Salamura Asma Yapraklarının Mikrobiyolojik ve Bazı Kimyasal Özellikleri/Microbiological and some Chemical Properties of Brined Grapevine Leaves Produced by Traditional and Industrial Methods. Atatürk Üniversitesi Ziraat Fakültesi Dergisi, 45(1), 15-19.

[9] Fleming, H. P., 1982 Fermented vegetables. In: Economic Microbiology, Vol. 7. Fermented Foods (ed. Rose, A. H.). Academic Press, London. pp. 227-258.
[10] Flòrez, A.B., Martín, P.A, Lòpez-Díaz, T.M., Mayo, B., 2007. Morphotypic and molecular identification of filamentous fungi from Spanish blue-veined Cabrales cheese, and typing of Penicillium roqueforti and Geotrichum candidum isolates. International Dairy Journal 17, 350-357.

[11] Gülcü, M., 2009. Yemeklik asma yaprağı üretimi, TC Tarım ve Köyişleri Bakanlığı, Tekirdă̆ Bağcılık Araştırma Enstitüsü, Çiftçi BroşürüYayın No: 22

[12] Harris, L.J., 1998. The Microbiology of Vegetable Fermentations, (B.J.B. WOOD, editor), Microbiology of Fermented Foods, Blackie Academic andProfessional, London, p. 45-72.

[13] Hesham, A. L. and Hashem M. M., 2010., Molecular genetic identification of yeast strains isolated from Egyptian soils for solubilization of inorganic phosphates and Growth Promotion of Corn Plants, J. Microbiol. Biotechnol, 21(1), 55-6.1 Daeschel, MA. Andersson, DE., Flemming, HP., 1987. Microbial ecology of fermenting plant materials Fems Microbiology Reviews 46 357-367

[14] Katsaboxakis,K.,Zoidou,E.;Athanasopoulos,E.P.;Balatsoura,B., 1986 Preservation of "Soultanina" leaf blades in brine Agris 10(1) p. 105-117

[15] Lõoke M., Kristjuhan K., Kristjuhan A., 2012. Yeast genomic DNA extraction with LiOAc-SDS (Protocol for: Extraction of genomic DNA from yeasts for PCR-based applications), BioTechniques Protocol Guide, 395

[16] Mezzasalma, V., Sandionigi, A., Bruni, I., Bruno, A., Lovicu, G., Casiraghi, M., \& Labra, M. (2017). Grape microbiome as a reliable and persistent signature of field origin and environmental conditions in Cannonau wine production. PloS one, 12(9), e0184615.

[17] Oliveira,E.S., Rosa, C.A., Morgano M. A., and Gil Eduardo Serra G.E., 2004. Fermentation characteristics as criteria for selection of cachaça yeast World Journal of Microbiology Biotechnology 20: 19-24

[18] Ozaki S, Fukuda S, Fujita T, Kishimoto N., 2008. RAPD analysis of salt-tolerant yeasts from contaminated seasoned pickled plums and their growth inhibition using food additives, Biocontrol Sci., 13(4):12530 .

[19] Praphailong W., Fleet G.H., 1997 The effect of $\mathrm{pH}$, sodium chloride, sucrose, sorbate and benzoate on the growth of food spoilage yeast

[20] Food Microbiology 14 459- 468

[21] Russell H. Vreeland, Lawrence I. Hochstein, 1992. The Biology of Halophilic Bacteria. CRC

[22] Sanjeev, K., Satyanarayana, T., 2001. Medium optimization for glucoamylase production by a yeast, Pichia subpelliculosa ABWF-64 in submerged cultivation- World Journal of Microbiology Biotechnology 17: 83-87

[23] Savard, T., Beaulieu, C., Gardner, N. J., and Champagne, C. P., 2002. Characterization of spoilage yeasts isolated from fermented vegetables and inhibition by lactic, acetic and propionic acids. Food Microbiology 19:363-373.

[24] Vasdinyei, R. and Dea'k T., 2003. Characterization of yeast isolates originating from Hungarian dairy products using traditional and molecular identification techniques, International Journal of Food Microbiology 86:123-130.

[25] Wessels , S., Axelsson, L., Hansen, E. B., De vuyst, L., Laulund, S., Lahteenmaki, L., Lindgren, S., Mollet, B., Salminen, S., Wright, A. V. 2004. The lactic acid bacteria, the food chain and their regulation. Trends in food science Technology, 25 498-505

[26] White, T. J., T. Bruns, S. Lee, and J. W. Taylor. 1990. Amplification and direct sequencing of fungal ribosomal RNA genes for phylogenetics. Pp. 315-322 In: PCR Protocols: A Guide to Methods and Applications, eds. Innis, M. A., D. H. Gelfand, J. J. Sninsky, and T. J. White. Academic Press, Inc., New York

[27] Wyder, M.T., Puhan, Z.,1999 Investigation of the yeast flora in smear ripened cheeses Milk Science International 54 330-333. 